\title{
Correlation between the Linear Type Traits and Milk Yields and its Composition in Dairy Cattle
}

\author{
Anupam Soni*, Sharad Mishra, A. K. Santra, Nishma Singh, Rupal Pathak, \\ M. D. Bobade, Ashutosh Dubey, Neetu Sonkar and Sudheer Bhagat
}

Department of Livestock Production and Management, College of Veterinary Science and Animal Husbandry, CGKV, Anjora, Durg 491001 India

*Corresponding author

\section{A B S T R A C T}

\section{Keywords}

Milk yields, Milk fat, Milk lactose, Milk protein, Linear type traits

\section{Article Info}

Accepted:

04 March 2020

Available Online:

10 April 2020

\begin{abstract}
The dairy enterprise is very crucial for developing countries to generate the income of poor people of rural areas. In present investigation, the milk yields were correlated with different type traits in early, mid lactation and overall. They showed that the negative or positive association with milk yields and composition $\mathrm{n}$ at early and mid lactation. In early lactation stage, the type traits such as chest width, rump width, udder depth, rear leg set rear view, rear udder height, fore udder attachment and front teat position were positively associated with milk production (yields). On other hand, stature, chest width, udder depth, udder cleft and rear udder heights were positively correlated with milk yields in mid lactation. Overall milk production, the positive association between type traits such as stature $(r=0.369)$, chest width $(r=0.338)$, rump angle $(r=0.333)$, rear leg set rear view ( $r$ $=0.158)$, rear udder height $(\mathrm{r}=0.069)$ and fore udder attachment $(\mathrm{r}=0.207)$ with milk yields. Beside this, stature only traits which were positively and significantly correlated with milk yields.
\end{abstract}

\section{Introduction}

Most of the countries the cattle are reared for mainly milk production with fat percentage in milk. Beside this, the cattle select for milk type traits for high milk yields and lower the immunity, reduced reproductive efficiency and longevity (Ptak et al., 2008; Samoré et al., 2010; Corrales et al., 2011). The conformation or linear type trait of animal is essential factors for the breeding and selection of dairy cattle. The longevity of animal largely depends on linear type traits especially the traits which are related to udder, feets and legs (Bunger et al., 2001; Ducrocq, 2001). These traits are important criteria during selection of animals as it is not only the better indicator of health condition (Saloniemi et al., 1986) but also a impression of its production performance and temperament (Blake and Mc Daniel, 1979). However, these traits vary with time period or physiological status of animals.

The milk yield can be tremendously affected by the poor udder conformation leading to udder deformities and sometimes such 
animals are more susceptible to mastitis resulting in huge economic loss. The shapes, location, strength and attachment of udder are heritable traits having ability to alter the morphological structure of cow's udder (Atkins, 2007). Dairy animal basically have open and well sprung fore and rear ribs with wide chest and sufficient body depth to support the ability to produce milk.

Linear type traits help in selection of superior cows, increasing profit, reduced disease occurrences and decrease the involuntary culling of cows (Valencia et al., 2008). The type traits also consider as indirect indicators for the improvement for better productive and reproductive performance. The type traits or conformation traits can be categorized into groups as body type traits, rump, udder and feet type traits (Corrales et al., 2011).

In high milk producing cows having higher rear udder height, loose fore udder attachment and weakly udder cleft or central ligament in comparision to low milk producing cows. Thus, any abnormalities in udder, legs and reproductive disorders reduced the productive lifespan of animals.

Animals with narrow chest width having high risk of culling, it necessary to measure the chest width. The rump angle with straight to moderate slope from hip to pin bone have been linked with less reproductive problems and less involuntary culling (Caraviello et al., 2004; Sewalem et al., 2004). Thus it may be the reason that the reduces the chances of reproductive problems in Sahiwal herd. In narrow rump width animals are susceptible to calving problems (Cue et al., 1990). Intermediate type of rear leg set is expected to possess the longer lifespan (Atkins and Shannon, 2002). Udder depth is positively correlated with length of productive life of animal (Larroque and Ducrocq, 2001).

\section{Materials and Methods}

\section{Source of Data}

Present experiment was conducted in a purebred Sahiwal cattle herd of Bull Mother Experimental Farm and Government Cattle Breeding Farm located at the campus of College of Veterinary Science \& Animal Husbandry, Anjora, Durg (C.G.). A total of 32 milch Sahiwal cows were selected for record milk production and linear type traits. All the linear type traits were measured and scored as per procedure described by International Committee for Animal Recording (ICAR, 2018).

\section{Feeding and management practices}

In present study, selected cows are kept in double row with concrete floor. The animals were given green fodder, dry fodder and concentrate as per their requirement and standard feeding schedule. The green fodder supplied to the cows includes Berseem, MP Chari, Sudan grass and local grasses. Dry fodder consisted of paddy straw and wheat straw. The concentrate mixture was fed during morning and evening at the time of milking. Drinking water was made available ad lib to all animals. Milking was done by hand milking method. Milk yield was recorded during morning and evening. Deworming, vaccination and other health care practices were followed as per standard method.

The linear type traits in Sahiwal cattle were measured as per the recommendation of ICAR (2018).

Stature: It is a vertical distance from top of spine in between hip to ground without touching cattle. It was recorded in centimeter.

Chest width: It is horizontal distance between top of front legs from inside. 
Rump angle: The angle of rump is measured from hip bone. When the cow was assessed from side, the slope from hip bone to pin bone was measured.

Rump width: It is distance between two pin bones assessed from behind.

Rear leg set (side view): The angle is measured at hock joint to claw assessed from the side.

Rear leg set (rear view): It was assessed from behind at the hock to fetlock.

Udder depth: It is difference in distance between from lower part of udder to hock joint.

Rear udder height: It is vertical distance between bottoms of vulva to milk secreting tissue.

Udder cleft: This trait was assessed from rear, depth of udder cleft measured at base of rear quarter with the help of $15 \mathrm{~cm}$ scale.

Fore udder attachment: It is attachment of fore udder with abdominal wall. This was assessed from side, the attachment was measured as angle, angle between udder and abdominal wall was measured.

Front teat placement: It was assessed from rear, the front teat position measured from centre of quarter.

\section{Statistical analysis}

Further to see the relation correlation coefficient between different linear type traits and milk yields were done as per Snedecor and Cochran (1989).

\section{Results and Discussion}

In present investigation, in early lactation stage, the type traits such as chest width $(\mathrm{r}=$ 0.329), rump width $(\mathrm{r}=0.61)$, udder depth $(\mathrm{r}$ $=0.037)$, rear leg set rear view $(r=0.08)$, rear udder height $(\mathrm{r}=0.39)$, fore udder attachment $(\mathrm{r}=0.227)$ and front teat position $(\mathrm{r}=0.43)$ were positively correlated with milk yields. Among this, stature was positively and significantly ( $p<0.001)$ correlated $(r=0.803)$ with milk yields. On other hand, traits like rump angle $(r=-0.411)$, rear leg set side view $(\mathrm{r}=-0.33)$ and udder cleft $(\mathrm{r}=-0.135)$ were negatively correlated with milk yields. On milk composition at early stage, stature, chest width, rump width, udder depth, rear udder height, fore udder height were negatively and rump angle, rear leg set rear view, rear leg set side view and udder cleft were positively correlated with milk fat. Likewise, stature, chest width, rump angle, rump width, rear leg set side view, udder cleft and front teat position were positively associated with milk protein and udder depth, rear leg set rear view, rear udder height and fore udder height were negatively correlated with milk protein. On other hand, the type traits such as stature, chest width, rump width, udder depth, fore udder attachment and front teat position were positively correlated with milk lactose and rest of the traits were negatively correlated with milk lactose (Table $1 \& 2$ ).

Similarly, the association between linear type traits and milk yields and its compositions at mid lactation stage. The traits such as rump angle $(r=-0.098)$ rump width $(r=-0.213)$, rear leg set rear view $(r=-0.206)$, rear leg set side view $(r=-0.265)$, fore udder attachment $(\mathrm{r}=-0.019)$ and front teat position $(\mathrm{r}=$ 0.136) were negatively correlated with milk yields and rest of traits (stature, chest width, udder depth, udder cleft and rear udder height) were positively correlated with milk yields. In milk composition at mid lactation stage, the stature, chest width, rump angle, rump width, udder depth, udder cleft and front teat position were positively associated with milk fat and rear leg set rear view and side view, rear udder height and fore udder attachment were negatively correlated with milk fat. Among this stature was positively and significantly $(\mathrm{p}<0.05)$ correlated with milk fat. Whereas, the milk protein were positively associated with traits such as chest 
width, rump width, udder depth, rear leg set rear view, rear leg set side view, rear udder height and fore udder attachment. Rest of this traits were negatively correlated them. The traits like, stature, chest width, rump angle, rump width, udder cleft and front teat position were negatively association with milk lactose and udder depth, rear leg set side view, rear leg set rear view, rear udder height and fore udder attachment were positively correlated with milk lactose (Table $1 \& 2$ ).

On pooled, the association between type traits such as stature $(\mathrm{r}=0.369)$, chest width $(\mathrm{r}=$ 0.338), rump angle ( $\mathrm{r}=0.333)$, rear leg set rear view $(\mathrm{r}=0.158)$, rear udder height $(\mathrm{r}=$ $0.069)$ and fore udder attachment $(r=0.207)$ were positively correlated with milk yields. Other traits such as rump width $(\mathrm{r}=-0.098)$, rear leg set side view $(r=-0.206)$, udder depth $(\mathrm{r}=-0.213)$, udder cleft $(\mathrm{r}=-0.265)$ and front teat position $(\mathrm{r}=-0.019)$ were negatively correlated with milk yields.

On other hand the milk composition, the traits such as stature, chest width, rump width, udder depth, rear udder height, fore udder attachment and front teat position were negatively correlated with milk fat. Beside this, stature $(\mathrm{p}<0.01)$ and front teat position $(\mathrm{p}<0.05)$ significantly correlated with milk fat. Rest of the traits was positively associated with milk fat. All the traits (stature, chest width, rump width and front teat position) negative and non significantly correlated with milk protein. Similarly, the milk lactose were positively associated with stature, chest width, rump angle, rump width, udder depth, fore udder attachment and front teat position, while, rear leg set rear view, rear leg set side view, rear udder height and udder cleft were positively correlated with milk lactose. Stature was positively and significantly $(\mathrm{p}<$ 0.05 ) correlated with milk lactose (Table 3 ).

According to Berry et al., (2004) type traits like fore udder attachment and rear udder height positively associated with milk yield. Whereas, udder depth was negatively associated with milk yield. The same authors also reported that the rear leg set rear view was positively associated with milk yields.

Table.1 Showing that correlation between linear type traits and milk yield in early and mid lactation

\begin{tabular}{|l|l|c|c|c|}
\hline S.No & \multicolumn{2}{|c|}{ Early lactation } & Mid lactation & Pooled \\
\hline Linear type traits & Correlation & Correlation & Correlation \\
\hline $\mathbf{1}$ & Stature & $0.803^{* *}$ & 0.338 & $0.369^{*}$ \\
\hline $\mathbf{2}$ & Chest width & 0.329 & 0.333 & 0.338 \\
\hline $\mathbf{3}$ & Rump angle & -0.411 & -0.098 & 0.333 \\
\hline $\mathbf{4}$ & Rump width & 0.61 & -0.213 & -0.098 \\
\hline $\mathbf{5}$ & Udder depth & 0.037 & 0.158 & -0.213 \\
\hline $\mathbf{6}$ & Rear leg set rear view & 0.08 & -0.206 & 0.158 \\
\hline $\mathbf{7}$ & Rear leg set side view & -0.33 & -0.265 & -0.206 \\
\hline $\mathbf{8}$ & Udder cleft & -0.135 & 0.069 & -0.265 \\
\hline $\mathbf{9}$ & Rear udder height & 0.39 & 0.207 & 0.069 \\
\hline $\mathbf{1 0}$ & Fore udder attachment & 0.227 & -0.019 & 0.207 \\
\hline $\mathbf{1 1}$ & Front teat position & 0.43 & -0.163 & -0.019 \\
\hline
\end{tabular}

* Significant at $\mathrm{p}<0.05,{ }^{* *}$ Significant at $\mathrm{p}<0.01$ 
Table. 2 Showing that correlation between linear type traits and milk composition in early and mid lactation

\begin{tabular}{|l|l|c|c|c|c|c|c|}
\hline S.No & \multicolumn{5}{|c|}{ Early lactation } & \multicolumn{3}{|c|}{ Mid lactation } \\
\hline & Linear type traits & Fat & Protein & Lactose & Fat & Protein & Lactose \\
\hline $\mathbf{1}$ & Stature & $-0.569^{*}$ & 0.151 & $0.707^{* *}$ & $0.517^{*}$ & -0.497 & $-0.650^{* *}$ \\
\hline $\mathbf{2}$ & Chest width & -0.177 & 0.214 & 0.230 & 0.117 & 0.080 & -0.254 \\
\hline $\mathbf{3}$ & Rump angle & 0.280 & 0.404 & -0.302 & 0.371 & -0.202 & -0.084 \\
\hline $\mathbf{4}$ & Rump width & -0.072 & 0.390 & 0.123 & 0.116 & 0.220 & -0.021 \\
\hline $\mathbf{5}$ & Udder depth & -0.122 & -0.348 & 0.096 & 0.075 & 0.149 & 0.284 \\
\hline $\mathbf{6}$ & Rear leg set rear view & 0.116 & -0.450 & -0.183 & -0.115 & 0.150 & 0.319 \\
\hline $\mathbf{7}$ & Rear leg set side view & 0.295 & 0.159 & -0.341 & -0.129 & 0.135 & 0.357 \\
\hline $\mathbf{8}$ & Udder cleft & 0.139 & 0.097 & -0.121 & 0.130 & -0.110 & -0.137 \\
\hline $\mathbf{9}$ & Rear udder height & -0.007 & -0.181 & -0.056 & -0.181 & 0.061 & 0.204 \\
\hline $\mathbf{1 0}$ & Fore udder attachment & -0.351 & -0.078 & 0.338 & -0.084 & 0.171 & 0.131 \\
\hline $\mathbf{1 1}$ & Front teat position & -0.427 & $0.516^{*}$ & 0.478 & 0.062 & -0.327 & -0.397 \\
\hline
\end{tabular}

* Significant at $\mathrm{p}<0.05,{ }^{* *}$ Significant at $\mathrm{p}<0.01$

Table.3 Showing that correlation between linear type traits and milk composition

\begin{tabular}{|l|l|c|c|c|}
\hline & Linear type traits & Fat & Protein & Lactose \\
\hline $\mathbf{1}$ & Stature & $-0.48^{* *}$ & 0.360 & $0.710^{* *}$ \\
\hline $\mathbf{2}$ & Chest width & -0.14 & 0.297 & 0.240 \\
\hline $\mathbf{3}$ & Rump angle & 0.10 & -0.182 & 0.002 \\
\hline $\mathbf{4}$ & Rump width & -0.05 & 0.133 & 0.055 \\
\hline $\mathbf{5}$ & Udder depth & -0.05 & -0.234 & 0.56 \\
\hline $\mathbf{6}$ & Rear leg set rear view & 0.121 & -0.251 & -0.159 \\
\hline $\mathbf{7}$ & Rear leg set side view & 0.224 & -0.048 & -0.338 \\
\hline $\mathbf{8}$ & Udder cleft & 0.075 & -0.041 & -0.040 \\
\hline $\mathbf{9}$ & Rear udder height & -0.06 & -0.016 & -0.038 \\
\hline $\mathbf{1 0}$ & Fore udder attachment & -0.30 & -0.013 & 0.266 \\
\hline $\mathbf{1 1}$ & Front teat position & $-0.36^{*}$ & 0.270 & 0.332 \\
\hline
\end{tabular}

* Significant at $\mathrm{p}<0.05,{ }^{* *}$ Significant at $\mathrm{p}<0.01$

In other research, the fore udder attachment was negative correlation with milk yields (Brotherstone 1994). On other hand, stature was positively associated with milk production (Short and Lawlor, 1992; Brotherstone, 1994; Parke et al., 1999; DeGroot et al., 2002). In few studies, type traits like chest width and rump width negatively associated with milk production (Meyer, Brotherstone and Hill, 1987; Brotherstone, 1994. It is clear that, cows having strong attachment of fore udder with and strong udder, thus these cows produce more milk production.

According to Norman et al., (1988) cows with looser fore udder attachments and deeper udders, thus, those cows produce more milk production. Jagtenberg and van Scheppingen (1994) reported that cows with poor teat placement are unlikely to be compatible with robotic milking systems. 
The negative phenotypic association of udder depth with milk yields and milk fat and milk protein was found. According to Norman et al., 1988 in jersey cows, the fore udder attachment and udder depth were highly negatively correlated with milk yields. Good udder of an animal has direct bearing on its productive life (Buenger et al., 2001).

Němcová et al., (2007) negative correlations between fore udder attachment, udder cleft and udder depth have with milk yield. DeGroot et al., (2002) reported that traits related to udder attachment had negative genetic relationship with milk yield, whereas udder capacity traits had

Positive relationship with milk yields. Rogers (1993) the negative association between milk yields and udder depth.

It is concluded that type traits are associated with both milk quality and quantity. In present investigation, Stature is only trait which significantly and positively correlated with milk yields in early lactation stage. The chest width, rear udder height and fore udder attachment are associated with milk yields. It is seen that cow having broad chest width, and strong udder attachment produce more milk as compared to other cows.

\section{References}

Atkins G. (2007). Using conformational anatomy to identify functionality in dairy cows. $27^{\text {th }}$ European Holstein and red Holstein conference, Denmark.

Atkins G. and Shannon J. (2002). Minimizing lameness through genetic selection. Advances in dairy technology. 14, 93.

Berry D.P., Buckley F. and Dillon P. (2004). Genetic relationships among linear type traits, milk yield, body weight, fertility and somatic cell count in primiparous dairy cows. Irish Journal of Agricultural and Food Research. 43,161-176.
Blake R.W. and McDaniel B.T. (1979). Relationships of udder conformation with labour and machine inputs to milk harvest in dairy cattle. Journal of Dairy Science. $62,475$.

Brotherstone S. (1994). Genetic and phenotypic correlations between linear type traits and production traits in Holstein-Friesian dairy cattle. Animal Production. 59, 183-187.

Buenger A., Ducrocq V. and Swalve H.H. (2001). Analysis of survival in dairy cows with supplementary data on type scores and housing systems from a region of northwest Germany. J Dairy Sci. 84, 1531-41.

Bunger A., Ducrocq V. and Swalve H.H. (2001). Analysis of survival in dairy cows with supplementary data on Type score and housing system from a region of NorthWest Germany. Journal of Dairy Science. 84, 1531-1541.

Caraviello D.Z., Weigel R.A. and Gianola, D. (2004). Analysis of the relationship between type traits and functional survival in U.S. Holstein cattle using a weibull proportional hazards models. Journal of Dairy Science. 87, 2677-2686.

Corrales J., Cerón M. and Cañas, J. (2011). Parámetros genéticos de características de tipo y producción en ganado Holstein del departamento de Antioquia. Revista MVZ Córdoba.17, 2870-2877.

Cue R.I., Monardes H.G. and Hayes J.F. (1990). Relationships of calving ease with type traits. Journal of Dairy Science. 73, 35863590.

DeGroot B.J., Keown J.F. and Van Vleck D. (2002) Genetic parameters and responses of linear type, yield traits, and somatic cell scores to divergent selection for predicted transmitting ability for type in Holsteins. Journal of Dairy Science. 85,1578-158,.

DeGroot B.J., Keown J.F., van Vleck L.D. and Marotz E.L. (2002). Genetic parameters and responses of linear type, yield traits, and somatic cell scores to divergent selection for predicted transmitting ability for type in Holsteins. Journal of Dairy Science. 85, $1578-1585$.

Ducrocq V. (2001). Illustration of trend validation test for longevity evaluation. Interbull bulletin. 27, 147-152. 
ICAR. (2018). Conformational recording of dairy cattle. Available at: www.icar.org/ documents/...../guidelines/.

Jagtenberg C.J. and Van Scheppingen A.T.J. (1994). Dieren selecteren op AMS. Inpasbaarheid automatisch melksystem stelt eisen aan de koe. Landbouwmechanisatie. $45,43-45$.

Larroque H. and Ducrocq V. (2001). Relationships between Type and longevity in the Holstein breed. Genetics Selection Evolution. 33, 39-59.

Meyer K., Brotherstone S. and Hill W.G. (1987). Inheritance of linear type traits in dairy cattle and correlations with milk production. Animal Production. 44, 1-10.

Němcová, E.; Štípková, M. and Zavadilová L. (2007). The relationship between somatic cell count, milk production and six linearly scored type traits in Holstein cows. Czech Journal of Animal Science. 52, 437- 446, 2007.

Norman H.D., Powell R.L., Wright J.R. and Cassell B.G. (1988). Phenotypic and genetic relationship between linear functional type traits and milk yield for five breeds. Journal of Dairy Science. 71, 18801896.

Parke P.J., Kennedy B.W., Dekkers J.C.M., Moore R.K. and Jairath L. (1999). Genetic and phenotypic parameter estimates between production, feed intake, feed efficiency, body weight and linear type in first lactation Holsteins. Canadian Journal of Animal Science. 79, 425-431.

Pe'rez-Cabal M. A. and Alenda R. (2002). Genetic relationships between lifetime profit and type traits in Spanish Holstein cows. Journal of Dairy Science. 85,34803491 .

Ptak E., Jagusiak W. and Zarnecki A. (2008).

\section{How to cite this article:}

Anupam Soni, Sharad Mishra, A. K. Santra, Nishma Singh, Rupal Pathak, M. D. Bobade, Ashutosh Dubey, Neetu Sonkar and Sudheer Bhagat. 2020. Correlation between the Linear Type Traits and Milk Yields and its Composition in Dairy Cattle. Int.J.Curr.Microbiol.App.Sci. 9(04): 174-180. doi: https://doi.org/10.20546/ijcmas.2020.904.022
Relationship between test day somatic cell score and conformation traits in Polish Holstein cattle. 59th Annual Meeting of the European Association for Animal Production. Vilnus, Lithuania. 1-6.

Rogers G.W. (1993). Index selection using milk yield, somatic cell score, udder depth, teat placement, and foot angle. Journal of Dairy Science.76, 664-670.

Saloneimi H, Grohn Y. and Syvajarvi J. (1986). An epidemiological and genetic study on registered diseases in finnish Ayrshire cattle II. Acta Veterinaria Scandinavica. 27,196208.

Samoré A.B., Rizzi R., Rossoni A. and Bagnato A. (2010). Genetic parameters for functional longevity, type traits, SCS, milk flow and production in the Italian Brown Swiss. Italian Journal of Animal Science. 9, 145-152.

Sewalem A., Kistemaker G.I., Milglior F. and Van Doormal B.J. (2004). Analysis for the relationship between survival in Canadian Holsteins using a weibull proportional hazards model. Journal of Dairy Science. 87, 3938-3946.

Short T.H. and Lawlor T.J. 1992. Genetic parameters of conformation traits, milk yield, and herd life in Holsteins. $J$ Dairy Sci. 75, 1987- 1998.

Snedecor G.W. and Cochran W.G. (1989). Statistical methods (seventh editions). Iowa, State University Press, Ames, Iowa (U.S.A).

Valencia M., Montaldo H.H. and Ruíz, F. (2008). Parámetros genéticos para características de conformación, habilidad de permanencia y producción de leche en ganado Holstein en México. Revista Técnica Pecuaria en México. 46, 235-248. 